\title{
Influence of international commitments against torture on prison indicators:
}

\section{measuring human rights}

Influência dos compromissos internacionais contra a tortura em indicadores prisionais: medindo os direitos humanos

Influencia de los compromisos internacionales contra la tortura en los indicadores penitenciarios: medición de los derechos humanos

Received: 01/01/2022 | Reviewed: 01/06/2022 | Accept: 01/11/2022 | Published: 01/13/2022

\author{
Cíntia da Silva Telles Nichele \\ ORCID: https://orcid.org/ 0000-0001-6685-1017 \\ Oswaldo Cruz Foundation - Sérgio Arouca National School of Public Health, Brazil \\ E-mail: cintiatelles.ensp@gmail.com \\ Aldo Pacheco Ferreira \\ ORCID: https://orcid.org/ 0000-0002-7122-5042 \\ Oswaldo Cruz Foundation - Sérgio Arouca National School of Public Health, Brazil \\ E-mail: aldoferreira@ensp.fiocruz.br
}

\begin{abstract}
The Optional Protocol to the Convention against Torture and Other Cruel, Inhuman or Degrading Treatment or Punishment created torture prevention mechanisms to enhance the protection of the human rights of persons in custody. The intention was to guarantee adequate treatment to the population most vulnerable to this type of aggression. However, does the pact generate positive effects for the countries that adhere to it? The study aims to assess the influence of the protocol on prison indicators. We used the two-sample t-test statistical method to compare the means of the indicators of countries that ratified the protocol and countries that did not, to verify whether the difference between the results was statistically significant. For this, we consider 5\% significance. The results showed the adult female population of non-ratifying countries is larger than that of ratifying countries. However, concerning male adults and the juvenile population, there was no statistical difference. Regarding prisoners without a sentence, there was also no difference in the average percentages between the two groups of countries. Mortality from external causes and suicide reached statistically higher rates in ratifying countries. For other causes (natural causes, homicide, accidental or other causes, and total deaths) the differences between the rates found were not significant.
\end{abstract}

Keywords: International cooperation; Human rights abuses; Prison violence; Statistical analysis.

\section{Resumo}

O Protocolo Facultativo à Convenção contra a Tortura e Outros Tratamentos ou Penas Cruéis, Desumanos ou Degradantes criou mecanismos de prevenção à tortura para ampliar a proteção dos direitos humanos das pessoas sob custódia. A intenção era garantir o tratamento adequado à população mais vulnerável a esse tipo de agressão. Mas será que o pacto de fato gera efeitos positivos aos países que o aderem? O objetivo do estudo é avaliar a influência do protocolo nos indicadores prisionais. Utilizou-se o método estatístico do teste $t$ de duas amostras para comparar as médias dos indicadores dos países que ratificaram o protocolo e dos países que não o fizeram para verificar se a diferença entre os resultados era estatisticamente significativa. Para tanto, consideramos 5\% de significância. Os resultados mostraram que a população adulta feminina dos países não ratificantes é maior do que a dos ratificantes. No entanto, em relação aos adultos do sexo masculino e à população jovem não houve diferença estatística. Sobre os presos sem sentença também não houve diferença nos percentuais médios entre os dois grupos de países. A mortalidade por causas externas e por suicídio atingiu taxas estatisticamente mais altas nos países que o ratificaram. Nas demais causas (causas naturais, homicídio, acidentais ou outras causas, e total de mortes) as diferenças entre as taxas encontradas não foram significativas.

Palavras-chave: Cooperação internacional; Violações dos direitos humanos; Violência na prisão; Análise estatística.

\section{Resumen}

El Protocolo Facultativo de la Convención contra la Tortura y Otros Tratos o Penas Crueles, Inhumanos o Degradantes creó mecanismos de prevención de la tortura para mejorar la protección de los derechos humanos de las personas detenidas. La intención era garantizar un tratamiento adecuado a la población más vulnerable a este tipo de agresiones. Pero, ¿el pacto genera realmente efectos positivos para los países que se adhieren a él? El objetivo del 
estudio es evaluar la influencia del protocolo en los indicadores penitenciarios. Utilizamos el método estadístico de prueba $\mathrm{t}$ de dos muestras para comparar las medias de los indicadores de los países que ratificaron el protocolo y los países que no lo hicieron, para verificar si la diferencia entre los resultados era estadísticamente significativa. Para ello, consideramos una significancia del 5\%. Los resultados mostraron que la población de mujeres adultas de los países que no lo ratificaron es mayor que la de los países que lo ratificaron. Sin embargo, en relación a la población masculina adulta y juvenil no hubo diferencia estadística. En cuanto a los presos sin sentencia, tampoco hubo diferencia en los porcentajes medios entre los dos grupos de países. La mortalidad por causas externas y por suicidio alcanzó tasas estadísticamente más altas en los países ratificantes. Para otras causas (causas naturales, homicidio, causas accidentales u otras y muertes totales) las diferencias entre las tasas encontradas no fueron significativas.

Palabras clave: Cooperación internacional; Violaciones de los derechos humanos; Violencia carcelaria; Análisis estadístico.

\section{Introduction}

After World War II, the prohibition of torture took root in international law (Nowak et al., 2019). As early as 1948, article fifth of the Universal Declaration of Human Rights determined that no person could be subjected to torture, cruel, inhuman, or degrading treatment or punishment (United Nations, 1948). In the following years, other treaties, such as the Convention of Human Rights (third article) (Council of Europe, 1950) and the Pact of San José (fifth article) (American States, 1969), also adopted a similar prohibition.

Despite all the regulations of the human right not to torture, this practice continued to be exercised around the world. Cases of torture in Latin American dictatorships and European practices in the colonization of Africa were emblematic and rekindled global concern about the subject. In 1973, the UN General Assembly placed the issue of torture on the agenda and the following year adopted the Declaration on the Protection of All Persons from Being Subjected to Torture and Other Cruel, Inhuman or Degrading Treatment or Punishment. Although the Declaration did not have the force of law, it was the first step towards the creation of binding legislation that would criminalize torture as a means of prevention. 11 years later the Convention against Torture and Other Cruel, Inhuman or Degrading Treatment or Punishment (CAT) (United Nations, 1984) emerges, which deals specifically with torture and which defines it legally and establishes its prohibition as a non-derogable human right (Nowak et al., 2019).

In 2002, the Optional Protocol to the Convention against Torture and Other Cruel, Inhuman or Degrading Treatment or Punishment (OPCAT) was adopted, requiring states parties to introduce mechanisms to prevent torture, including overseeing the treatment of persons in custody (United Nations, 2002). The CAT demanded prevention and the OPCAT expanded protection and further CAT's realization by establishing a monitoring system in places of deprivation of liberty (Murray et al., 2011). The OPCAT intended to prevent torture in the population most vulnerable to suffering this type of aggression since places of deprivation of liberty can create an environment conducive to inhumane and cruel treatment (Weller, 2019).

This brief historical account of the evolution of international law against torture demonstrates that there is solid legal protection. However, the question that arises is whether the OPCAT influences the practice of the countries that ratify it. The scientific literature has addressed this issue in several aspects. Previous studies analyzed the applicability of the OPCAT in the context of places of detention at airports and other border areas and found that this instrument facilitated regular visits to these international areas, reinforcing prevention and respect for human rights (Edwards, 2008; Wolf \& Watson, 2009). Another analysis examined whether the OPCAT strengthened protection against torture in Europe and concluded that it did indeed strengthen existing national preventive mechanisms (Beco, 2011). A case study in Australia found that the implementation of the OPCAT played a more important role than that of the CAT, because regular protocol inspections, as preventive measures, have a greater potential to make a real difference to prisoners' lives than regular inspections reactive measures of the convention (Fletcher, 2012). In 2013, a prospective comparison was made between the possible effects of the CAT and the 
Research, Society and Development, v. 11, n. 1, e49611125288, 2022

(CC BY 4.0) | ISSN 2525-3409 | DOI: http://dx.doi.org/10.33448/rsd-v11i1.25288

OPCAT where it was statistically demonstrated that the protocol would be more likely to change the structures of its member states and improve human rights performance (Nguyen, 2013). A survey was also carried out to verify whether adherence to the OPCAT was related to aid policies and programs from rich and democratic countries to other countries, and found no evidence that ratification of the treaty did not produce significant increases in aid (Nielsen \& Simmons, 2015).

In more recent works in the literature, we find an analysis of the effects of the OPCAT on the fulfillment of the rights of persons with disabilities deprived of liberty, which demonstrated positive effects in the prevention of torture and illtreatment (Sveaass \& Madrigal-Borloz, 2017). Another article discussed whether New Zealand, which was an early adopter of the OPCAT, had improved the protection of the human rights of persons deprived of liberty, and considered that a solid foundation of protection had been developed in the country, but the challenge remains adequacy of funding to meet treaty objectives (White, 2019). There was also a survey involving European countries to determine how the OPCAT preventive mechanisms are implemented, and it showed that the practice was effective, as these mechanisms were installed and developed quickly (Hardwick \& Murray, 2019).

From this review, it is noted that scientific studies on the effects of the OPCAT did not explore possible changes in the scenario of indicators. Statistical analysis could be an adequate tool to measure the influence of the OPCAT in the countries that joined it by comparing the results in prison indicators and our work intends to provide this contribution to the scientific literature. Therefore, this study aims to assess the influence of OPCAT on prison indicators.

\section{Methodology}

This quantitative study used inferential statistics to assess the influence of the OPCAT on prison indicators. First, we present the situation of the countries' international commitment to both the OPCAT and the CAT. Although the main research interest was the analysis of the OPCAT, it was important to know the commitment to the main treaty to see if there was a difference in the degree of adherence between the convention and its optional protocol. We used data from the Office of the United Nations High Commissioner for Human Rights (OHCHR) (2021), which shows which countries are committed to the CAT and the OPCAT and the date of accession. To make this comparison, we do not perform inferential statistical tests, as we work with data from the universe (from all countries in the world). We organize the results into time series graphs by continental region to illustrate the evolution of country membership over time. We consider as committed only the countries that have ratified the treaties. The signatories (countries that signed but did not ratify the treaty) were considered uncommitted, as mere signing does not make the treaty mandatory law.

Concerning prison indicators, we use the United Nations Office on Drugs and Crime (UNODC) (2019) databases. We worked with the following indicators: rate of persons held by age group, and sex per 100,000 population (variables: adults male, adults female, total adults, juveniles male, juveniles female, total juveniles, total persons); percentage of persons held unsentenced by sex, and length of detention (variables: unsentenced males, unsentenced females, more than 12 months, total unsentenced); percentage of prison capacity, and rate of mortality in prison per 100,000 prisoners (variables: natural causes, external causes, intentional homicide, suicide, accidental and other causes, total deaths).

The objective was to compare the rates and proportions of the indicators between the group of OPCAT ratifying countries and the group of non-OPCAT ratifying countries. For each year, we calculated the mean of the ratifying and nonratifying countries variable to check whether there was a difference between these two results. As the UNODC database did not have data from all countries in the world, that is, we worked with samples, we performed the two-sample t-test (Kim, 2015) to determine whether the difference between the means found was statistically significant. Our null hypothesis was that the means were equal, therefore the alternative that the difference in means is not equal to zero (bilateral tests). To decide whether 
in the t-test we would use equal variances or not, we applied the f-test to compare two variances before each t-test (Morettin $\&$ Bussab, 2010). When the p-value of the f-test was significant, we applied the t-test for unequal variances (Welch's t-test), and when it was not significant, for equal variance (Limentani et al., 2005).

We used the $\mathrm{R}$ software (version 4.1.2), with the $\mathrm{R}$ Commander interface to run the calculations. The significance level was $5 \%$ for all statistical tests applied in the study. We approximate all the results of the means to 2 decimal places and the p-values to 3 decimal places. Regarding the research limits, it is important to emphasize that we considered all distributions as approximately normal, and the samples used were those of the countries that were available in the database (they were not randomly chosen).

Previous works that also used statistical methods to compare the evolution of indicators and infer the effects of international human rights treaties on the population methodologically supported this study (Tait et al., 2019; Cole, 2015; Wilson \& Daar, 2013; Palmer et al., 2009). However, none of them specifically used the two-sample t-test. In this sense, the method built in our work is innovative and may inspire future research in this field.

\section{Results}

The CAT has an expressive adhesion, with the ratification of 171 countries, which represents the commitment of approximately $88 \%$ of the countries in the world. However, when comparing the degree of adherence between regions, an imbalance is observed. Figure 1 shows the evolution of the ratification of the CAT from its entry into force in 1987 until the year 2021. Europe achieved $100 \%$ commitment in 2006. Africa ranks second-best in terms of ratification, with $96 \%$. The Eastern Mediterranean, with $90 \%$, and the Americas with $80 \%$ also present rates compatible with the world average. The lowest levels of adherence, which differ from the rest of the regions, are from the Western Pacific and South-East Asia, with, respectively, 59\% and 64\% commitment. The Western Pacific showed a trend of growth in adherence over the last 10 years, but it continues to show a percentage of commitment below the world average. South-East Asia has been stagnant since 2007.

Figure 1 Time series of ratification of Convention against Torture and Other Cruel, Inhuman or Degrading Treatment or Punishment and its OPCAT, by regions, 1985-2021
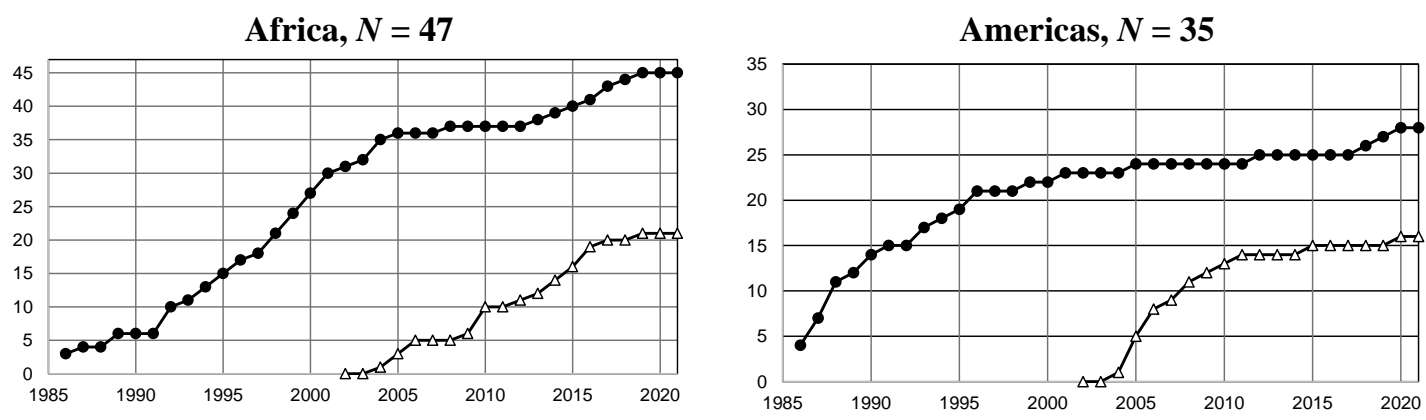

South-East Asia, $N=11$

Europe, $N=\mathbf{5 3}$ 

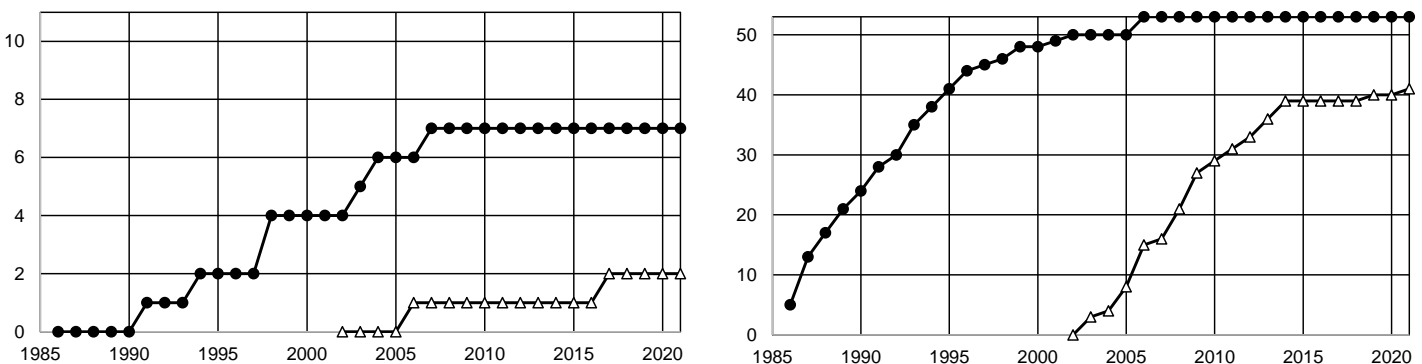

Eastern Mediterranean, $N=21$
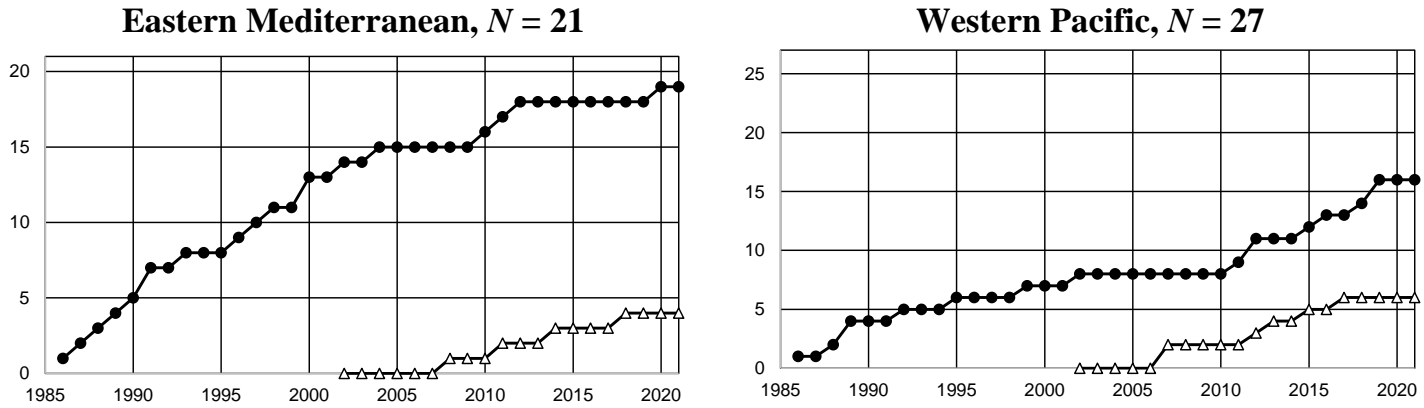

Convention against Torture and Other Cruel, Inhuman or Degrading Treatment or Punishment (CAT)

Optional Protocol to the Convention against Torture and Other Cruel, Inhuman or Degrading Treatment or Punishment (OPCAT)

Fonte: Autores.

The worldwide commitment to the OPCAT is less than to the CAT. Today, the OPCAT has 90 States Parties, that is, just under half of the countries in the world (approximately 46\%). Figure 1 also shows the evolution of OPCAT membership from 2002, the year it entered into force, until 2021. Europe has the highest degree of membership compared to other regions, with $77 \%$ of ratifying countries. It registered a growth trend until the years 2015 and since then it has remained stagnant with no new adhering country. The Americas and Africa appear next in the ranking, but with lower rates, respectively $46 \%$ and 45\%. As observed in Europe, the Americas and Africa showed a growth trend until the years 2015 approximately, but the subsequent years were of a smaller scale increase. The regions of Western Pacific (22\%), Eastern Mediterranean (19\%), and South-East Asia (18\%) are the least committed to the OPCAT. The Western Pacific and South-East Asia already had the worst CAT adherence rates. The Eastern Mediterranean showed $90 \%$ adherence of CAT and 19\% of OPCAT, being the region with the greatest difference found between the involvements of both treated.

Table 1 shows the averages of persons held by age groups and sex of countries that ratified the OPCAT and countries that did not ratify the OPCAT in the period from 2003 to 2019. It also presents the result of the p-value of the t-test that compares the difference between the means, indicating whether they were statistically significant. 
Research, Society and Development, v. 11, n. 1, e49611125288, 2022

(CC BY 4.0) | ISSN 2525-3409 | DOI: http://dx.doi.org/10.33448/rsd-v11i1.25288

Table 1 Persons held averages by age group, and sex of countries that have ratified the OPCAT and countries that have not ratified the OPCAT, and p-value of the two-sample t-test, rates per 100.000 population, 2003-2019.

\begin{tabular}{|c|c|c|c|c|c|c|c|c|c|c|c|c|c|c|c|c|c|c|c|c|c|}
\hline & \multicolumn{3}{|c|}{ Adults male } & \multicolumn{3}{|c|}{ Adults female } & \multicolumn{3}{|c|}{ Total adults } & \multicolumn{3}{|c|}{ Juveniles male } & \multicolumn{3}{|c|}{ Juveniles female } & \multicolumn{3}{|c|}{ Total juveniles } & \multicolumn{3}{|c|}{ Total persons } \\
\hline & $\mathrm{PHr}$ & $\mathrm{PHn}$ & $p$-value & $\mathrm{PHr}$ & PHn & $p$-value & $\mathrm{PHr}$ & $\mathrm{PHn}$ & $p$-value & $\mathrm{PHr}$ & $\mathrm{PHn}$ & $p$-value & $\mathrm{PHr}$ & PHn & $p$-value & $\mathrm{PHr}$ & PHn & $p$-value & $\mathrm{PHr}$ & $\mathrm{PHn}$ & $p$-value \\
\hline 2003 & 250.05 & 93.27 & 0.221 & 16.12 & 32.00 & 0.068 & 198.56 & 264.46 & 0.226 & 45.28 & 28.75 & 0.586 & 1.97 & 10.12 & 0.112 & 16.03 & 38.52 & 0.177 & 154.54 & 183.01 & 0.281 \\
\hline 2004 & 76.79 & 52.83 & 0.127 & 21.95 & 39.99 & 0.072 & 217.89 & 339.29 & 0.138 & 7.53 & 50.51 & 0.476 & 3.43 & 6.40 & 0.344 & 20.04 & 27.37 & 0.407 & 52.16 & 95.09 & 0.158 \\
\hline 2005 & 05.40 & 75.18 & 0.162 & 19.89 & 43.30 & $0.011^{*}$ & 220.77 & 268.71 & 0.240 & 7.72 & 42.36 & 0.756 & 1.58 & 4.39 & 0.362 & 16.97 & 19.83 & 0.602 & 49.07 & 73.15 & 0.280 \\
\hline 2006 & 397.64 & 732.85 & 0 & 21.41 & 4 & $0.006^{*}$ & & & & & & & 05 & & & 16.57 & 18.94 & & 158.00 & 3.62 & 0.211 \\
\hline 2007 & 392.61 & 675.46 & 0.079 & 18.64 & 46.54 & $0.034^{*}$ & 195.12 & 329.84 & $\mathbf{0 . 0 2 3}^{*}$ & 31.83 & 48.83 & & 1.96 & 5.27 & 272 & 15.84 & 19.16 & 0.535 & 150.72 & 199.80 & 0.085 \\
\hline 2008 & 416.13 & 656.32 & 0.115 & 19.99 & 41.35 & $0.039^{*}$ & 209.04 & 318.61 & 0.056 & 33.24 & 39.27 & 0.627 & 1.99 & 4.08 & .400 & 17.16 & 16.47 & 0.887 & 161.53 & 192.98 & 0.254 \\
\hline 2009 & 484.86 & 634.07 & 0.238 & 21.69 & 39.41 & $0.030^{*}$ & 240.94 & 327.48 & 0.165 & 39.21 & 46.26 & 0637 & 2.52 & 8.64 & 75 & 20.17 & 23.98 & 0.584 & 181.12 & 199.11 & 0.562 \\
\hline 2010 & 470.06 & 688.07 & 0.086 & 22.48 & 41.76 & $0.026^{*}$ & 235.85 & 339.33 & & 9.84 & 42.07 & & 1.74 & 3.93 & & 20.97 & 21.28 & & 172.22 & 187.26 & 0.553 \\
\hline 2011 & 476.74 & 702.96 & & 23.61 & & & 240.31 & & & 3.68 & & & 1.89 & & & 20.59 & 28 & & 174.16 & 201.23 & 0.376 \\
\hline 2012 & 460.90 & 622.51 & 0.134 & 24.92 & 37.46 & 0.086 & 233.79 & 319.23 & 0.124 & 30.65 & 35.59 & 0.631 & 1.65 & 3.16 & 10 & 16.88 & 19.13 & 0.923 & 175.40 & 181.71 & 0.784 \\
\hline 2013 & 436.97 & 735.61 & 0.159 & 23.29 & 38.77 & 0.061 & 222.75 & 367.84 & 0.164 & 27.23 & 52.69 & 0.263 & 1.31 & 2.82 & 0.329 & 15.29 & 25.94 & 0.314 & 170.09 & 182.46 & 0.587 \\
\hline 2014 & 439.92 & 722.59 & 0.147 & 23.24 & 41.64 & $\mathbf{0 . 0 3 9}^{*}$ & 223.02 & 359.33 & 0.141 & 22.22 & 46.32 & 0.202 & 1.02 & 5.03 & 0.236 & 12.57 & 27.77 & 0.117 & 163.77 & 170.13 & 0.772 \\
\hline 2015 & 408.84 & 780.56 & & 21.30 & & & 209.19 & & & 7.42 & & & 0.91 & 1.5 & & 10.24 & 22.96 & & 157.43 & 199.94 & 0.191 \\
\hline 2016 & 448.35 & 850.50 & & 22.49 & 46.10 & $0^{0.023^{*}}$ & 242.97 & 445.47 & 0.072 & 19.12 & 52.18 & $0.041^{*}$ & 0.98 & 8.11 & 0.291 & 11.04 & 28.46 & 0.193 & 161.16 & 205.70 & 0.173 \\
\hline 2017 & 431.32 & 742.47 & $0.041^{*}$ & 23.46 & 47.10 & 0.061 & 223.79 & 373.48 & 0.054 & 16.32 & 33.81 & 0.341 & 1.06 & 10.12 & 0.304 & 9.34 & 20.53 & 0.318 & 162.45 & 218.99 & $\mathbf{0 . 0 3 0}^{*}$ \\
\hline 2018 & 454.04 & 733.21 & 0.055 & 25.76 & 51.76 & $0.028^{*}$ & 235.82 & 394.29 & $0.037^{*}$ & 25.22 & 35.54 & 0.549 & 1.31 & 8.20 & 0.280 & 12.71 & 21.19 & 0.453 & 156.69 & 240.38 & $0.034^{*}$ \\
\hline 2019 & 460.53 & 782.68 & 0.081 & 28.16 & 53.94 & $\mathbf{0 . 0 2 3}^{*}$ & 246.16 & 411.05 & 0.054 & 19.94 & 34.90 & 0.541 & 1.11 & 13.63 & 0.273 & 9.78 & 34.65 & 0.134 & 164.21 & 259.78 & $0.045^{*}$ \\
\hline
\end{tabular}

PHr: averages of persons held of countries that have ratified the OPCAT, rates per 100.000 population

PHn: averages of persons held of countries that have not ratified the OPCAT, rates per 100.000 population

*bold: significant $p$-value, considering $5 \%$ significance

Sources: UNODC (2019); OHCHR (2021) 
Research, Society and Development, v. 11, n. 1, e49611125288, 2022

(CC BY 4.0) | ISSN 2525-3409 | DOI: http://dx.doi.org/10.33448/rsd-v11i1.25288

All average adult incarceration rates (both males, females, and total) of non-ratifying countries were higher than the average rates of ratifying countries. However, in the case of adults male, this difference was only statistically significant in 2017. In the case of adults female, statistical significance appeared in most of the years analyzed, that is, in 11 of the 17 years. The total number of adults was only statistically different in 2007 and 2018. It is noteworthy that the magnitude of the rates of adults male is substantially higher than that of adults female. The average rate of adult males in the sample of non-ratifying countries reached the rate of 852.83 per 100,000 inhabitants in 2004, while the highest rate of adult females in the sample was 53.94 per 100,000 inhabitants in 2019 in non-ratifying countries.

In the juveniles, the highest averages of rates recorded were also from non-ratifying countries in most observations. Exceptions occurred in 2003 about juveniles male, and in 2008 about the total juveniles. Despite the difference between the average rates of juveniles in the samples of the two groups of countries, this difference was only significant in 2016 in the case of juveniles male. As observed in the adults, the magnitude of juveniles male is greater than that of juveniles female. In the years 2015 and 2016, the average rates of juveniles female in the sample of ratifying countries did not reach 1 per 100,000 inhabitants, while the minimum mark for the rate of juveniles male was 16.32 per 100,000 inhabitants calculated in the year 2017 in the sample ratifying countries.

Considering the total persons, once again it is observed that all the averages of the sample rates of the non-ratifying countries are higher than those of the ratifying countries. This difference was statistically significant in the years 2017 to 2019 . Adults constitute the largest group of prisoners compared to juveniles, at least with the countries in the sample. This is true for the groups of ratifying and non-ratifying countries. The total adults in the sample reached an average rate between 195.12 and 445.47 of adults imprisoned per 100,000 inhabitants in the period, while the total number of juveniles in the sample was between the range of 9.34 and 38.52 juveniles imprisoned per 100,000 inhabitants.

The results of the tests applied to assess whether there was a difference in the percentage of people imprisoned without a sentence, and prison capacity between the group of ratifying and non-ratifying countries are shown in Table 2 . The proportion of both males and females unsentenced was higher in non-ratifying countries in 2015. The difference was small, approximately $5 \%$ in the case of males and less than $1 \%$ in the case of females, which was confirmed by the statistical test, which showed no significance in the difference. 
Research, Society and Development, v. 11, n. 1, e49611125288, 2022

(CC BY 4.0) | ISSN 2525-3409 | DOI: http://dx.doi.org/10.33448/rsd-v11i1.25288

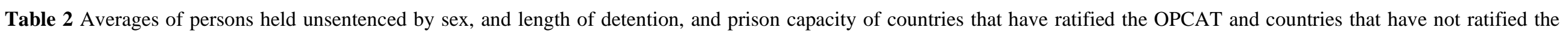
OPCAT, and p-value of the two-sample t-test, percentage of unsentenced prisoners, 2003-2018.

\begin{tabular}{|c|c|c|c|c|c|c|c|c|c|c|c|c|c|c|c|}
\hline & \multicolumn{3}{|c|}{ Unsentenced males } & \multicolumn{3}{|c|}{ Unsentenced females } & \multicolumn{3}{|c|}{ More than 12 months } & \multicolumn{3}{|c|}{ Total unsentenced } & \multicolumn{3}{|c|}{ Total prison capacity } \\
\hline & PUr & PUn & $p$-value & PUr & PHn & $p$-value & PUr & PUn & $p$-value & PUr & PUn & $p$-value & $\mathrm{PCr}$ & $\mathrm{PCn}$ & $p$-value \\
\hline 2003 & - & - & - & - & - & - & - & - & - & 27.20 & 33.75 & 0.360 & 105.19 & 111.15 & 0.372 \\
\hline 2004 & - & - & - & - & - & - & - & - & - & 26.31 & 31.86 & 0.291 & 118.17 & 110.05 & 0.574 \\
\hline 2005 & - & - & - & - & - & - & - & - & - & 28.46 & 30.05 & 0.811 & 118.99 & 122.05 & 0.788 \\
\hline 2006 & - & - & - & - & - & - & - & - & - & 29.38 & 27.27 & 0.760 & 127.78 & 120.51 & 0.587 \\
\hline 2007 & - & - & - & - & - & - & - & - & - & 28.68 & 28.50 & 0.976 & 118.59 & 121.37 & 0.814 \\
\hline 2008 & - & - & - & - & - & - & - & - & - & 26.46 & 29.16 & 0.614 & 119.40 & 118.79 & 0.963 \\
\hline 2009 & - & - & - & - & - & - & - & - & - & 27.78 & 29.82 & 0.700 & 120.07 & 115.83 & 0.430 \\
\hline 2010 & - & - & - & - & - & - & - & - & - & 27.42 & 28.79 & 0.781 & 128.28 & 117.81 & 0.470 \\
\hline 2011 & - & - & - & - & - & - & - & - & - & 26.82 & 24.40 & 0.616 & 123.00 & 120.41 & 0.861 \\
\hline 2012 & - & - & - & - & - & - & - & - & - & 27.20 & 28.69 & 0.768 & 129.08 & 107.68 & 0.058 \\
\hline 2013 & - & - & - & - & - & - & 23.60 & 30.98 & 0.761 & 25.31 & 27.93 & 0.587 & 114.96 & 109.98 & 0.685 \\
\hline 2014 & - & - & - & - & - & - & 20.50 & 21.87 & 0.931 & 27.05 & 29.59 & 0.656 & 114.16 & 126.93 & 0.317 \\
\hline 2015 & 19.68 & 24.81 & 0.459 & 1.53 & 1.73 & 0.692 & 20.50 & 23.37 & 0.833 & 28.16 & 28.01 & 0.978 & 115.20 & 126.33 & 0.510 \\
\hline 2016 & - & - & - & - & - & - & 20.91 & 29.71 & 0.462 & 27.33 & 30.32 & 0.540 & 113.09 & 128.62 & 0.246 \\
\hline 2017 & - & - & - & - & - & - & 20.05 & 14.81 & 0.590 & 27.76 & 32.39 & 0.303 & 110.84 & 134.54 & 0.115 \\
\hline 2018 & - & - & - & - & - & - & - & - & - & - & - & - & 125.32 & 145.90 & 0.275 \\
\hline
\end{tabular}

PUr: averages of persons held unsentenced of countries that have ratified the OPCAT, percentage of unsentenced prisoners

PUn: averages of persons held unsentenced of countries that have not ratified the OPCAT, percentage of unsentenced prisoners

"-": missing data

Sources: UNODC (2019); OHCHR (2021) 
Research, Society and Development, v. 11, n. 1, e49611125288, 2022

(CC BY 4.0) | ISSN 2525-3409 | DOI: http://dx.doi.org/10.33448/rsd-v11i1.25288

The proportion of persons held for more than 12 months unsentenced was also higher in the sample of non-ratifying countries in the period from 2013 to 2016. Only in 2017 did ratifying countries in the sample present a higher proportion. However, in none of these years was the difference significant. About the total unsentenced, in most of the years observed, non-ratifying countries had the highest proportions. Exceptions occurred in the years 2006, 2007, 2011, and 2013. These differences were also not significant.

In terms of prison capacity, differently from what has been observed so far, ratifying countries had higher average occupancy percentages than non-ratifying countries in 8 observations, while in the other 8 the situation was reversed. Even in this case, these differences may have been random, since statistical significances were not found either. It is worth mentioning that throughout the period observed, samples from countries in both groups had an average percentage of prison capacity above $100 \%$, which means prison overcrowding.

Table 3 presents the averages of mortality rates from causes of death per 100,000 prisoners from the ratifying and non-ratifying countries and the p-value of the test of the difference between the means. 
Research, Society and Development, v. 11, n. 1, e49611125288, 2022

(CC BY 4.0) | ISSN 2525-3409 | DOI: http://dx.doi.org/10.33448/rsd-v11i1.25288

Table 3 Averages of mortality in prison by causes of death of countries that have ratified the OPCAT and countries that have not ratified the OPCAT, and p-value of the two-sample ttest, rates per 100.000 prisoners.

\begin{tabular}{|c|c|c|c|c|c|c|c|c|c|c|c|c|c|c|c|c|c|c|}
\hline & \multicolumn{3}{|c|}{ Natural causes } & \multicolumn{3}{|c|}{ External causes } & \multicolumn{3}{|c|}{ Intentional homicide } & \multicolumn{3}{|c|}{ Suicide } & \multicolumn{3}{|c|}{ Accidental/other causes } & \multicolumn{3}{|c|}{ Total deaths } \\
\hline & $\mathrm{PMr}$ & PMn & $p$-value & $\mathrm{PMr}$ & PMn & $p$-value & $\mathrm{PMr}$ & PMn & $p$-value & $\mathrm{PMr}$ & PMn & $p$-value & $\mathrm{PMr}$ & PMn & $p$-value & $\mathrm{PMr}$ & PMn & $p$-value \\
\hline 2010 & - & - & - & 229.06 & 120.96 & $0.022^{*}$ & 10.59 & 0.51 & 0.054 & 57.96 & 30.42 & $0.048^{*}$ & - & - & - & 290.15 & 191.20 & 0.130 \\
\hline 2011 & - & - & - & 238.08 & 129.48 & $0.018^{*}$ & 11.18 & 9.90 & 0.903 & 70.88 & 20.14 & $0.000^{*}$ & - & - & - & 269.04 & 192.34 & 0.111 \\
\hline 2012 & - & - & - & 235.17 & 196.70 & 0.622 & 13.91 & 11.83 & 0.848 & 60.52 & 165.20 & 0.457 & - & - & - & 299.29 & 324.19 & 0.858 \\
\hline 2013 & 183.75 & 133.15 & 0.478 & 253.57 & 187.51 & 0.160 & 11.41 & 7.91 & 0.626 & 80.21 & 42.70 & 0.275 & 92.05 & 21.04 & 0.242 & 328.45 & 275.75 & 0.426 \\
\hline 2014 & 184.55 & 70.66 & 0.072 & 248.56 & 167.05 & $0.049^{*}$ & 10.59 & 3.79 & 0.201 & 60.39 & 29.92 & $0.028^{*}$ & 38.28 & 31.68 & 0.896 & 317.63 & 247.96 & 0.210 \\
\hline 2015 & 237.86 & 143.89 & 0.181 & 261.84 & 143.72 & $0^{.003^{*}}$ & 16.85 & 11.56 & 0.541 & 106.40 & 19.22 & 0.058 & 28.52 & 21.30 & 0.638 & 362.20 & 215.60 & $0.014^{*}$ \\
\hline 2016 & 255.21 & 127.35 & $0.015^{*}$ & 232.51 & 269.17 & 0.675 & 15.32 & 5.75 & 0.215 & 66.10 & 20.70 & $0.000^{*}$ & 33.98 & 245.36 & 0.307 & 334.34 & 354.59 & 0.869 \\
\hline 2017 & 245.46 & 213.84 & 0.615 & 225.16 & 330.23 & 0.523 & 15.07 & 8.46 & 0.668 & 82.69 & 296.49 & 0.423 & 10.87 & 16.46 & 0.468 & 334.01 & 489.32 & 0.527 \\
\hline 2018 & 243.22 & 206.60 & 0.549 & 233.10 & 139.51 & 0.117 & 16.17 & 9.15 & 0.696 & 74.18 & 24.16 & $0.021^{*}$ & 26.69 & 22.07 & 0.819 & 346.76 & 213.63 & 0.069 \\
\hline
\end{tabular}

PMr: averages of mortality in prison of countries that have ratified the OPCAT, rates per 100.000 prisoners

PMn: averages of mortality in prison of countries that have not ratified the OPCAT, rates per 100.000 prisoners

"bold: significant $p$-value, considering 5\% significance

"-": missing data

Sources: UNODC (2019); OHCHR (2021) 
Research, Society and Development, v. 11, n. 1, e49611125288, 2022

(CC BY 4.0) | ISSN 2525-3409 | DOI: http://dx.doi.org/10.33448/rsd-v11i1.25288

The sample of ratifying countries had higher averages than those of non-ratifying countries in rates for natural deaths throughout the period. However, the difference was only statistically significant in 2016. In external causes, the sample of signatory countries also had higher rates, except in 2016 and 2017. The differences reached significance in 2010, 2011, 2014, and 2015. Regarding deaths from intentional homicide, all the average rates of the ratifying countries analyzed were higher than those of non-ratifying countries, but the difference was not significant in any case. Suicide cases were also more numerous in the sample of signatory countries, except for the years 2012 and 2017, and the difference between the means was significant in 5 of the 9 years analyzed. Deaths from accidents or other causes were higher in signatory countries in most years, but without statistical significance. Finally, the global analysis of total deaths showed that, although there was a fluctuation in terms of the group of countries in the sample with the highest rates, these differences were only statistically relevant in the year 2015 .

\section{Discussion}

The results showed a substantial difference in commitment between the CAT and the OPCAT and this has repercussions in legal terms. The CAT was created to make the fight against torture and other cruel treatment more effective (United Nations, 1984). To achieve them, the convention requires States Parties to take three steps: criminalize torture in their respective domestic laws; recognize the victims' right to reparation; and enable means of prevention (Nowak et al., 2019). Despite addressing prevention, the CAT gives greater weight to repressive actions in its text. There is no doubt that sanction mechanisms are important in policies to combat torture. However, from the point of view of human dignity, the objective must be prevention. In this sense, the OPCAT has a fundamental role, because it establishes a system of regular visits to places of deprivation of liberty precisely to avoid torture. Greater adherence to the CAT compared to the OPCAT may demonstrate that most countries are more committed to post-torture actions than to actions that would prevent it. Even if it were possible to prove that torturers are being increasingly punished for their criminal acts, this achievement would not be very successful for human rights purposes, if it were not observed that the cases of torture and ill-treatment have decreased. What is meant is that the international effort against torture should not be about punishing the torturer, but about preventing torture. This difference in adherence between the main convention and its respective optional protocol was also observed in relation to the Convention on the Elimination of All Forms of Discrimination against Women (Nichele et al., 2021a; Nichele \& Ferreira, 2020) and in relation to the Convention on the Rights of the Child (Nichele et al., 2021b). In general, the protocols function as the executive arms of the convention, and the lower levels of commitment to the protocol demonstrate that countries are not yet fully engaged in the effective implementation of the rights guaranteed in the conventions.

Regarding the division of the prison population by age groups, we can say that there is no difference between the adult and youth population when comparing countries committed to the OPCAT with those not committed. When comparing the rate of prisoners by sex, it is possible to see that the population of female adults is greater in countries not committed to the OPCAT. The literature shows in a study involving prisoners in the United Kingdom that the levels of mental illness of female prisoners are significantly higher than that of men (Tyler et al., 2019). One of the factors reported in the study for the onset or worsening of these disorders is the psychosocial experience of prison, and torture and other cruel treatments certainly contribute to the worsening of this scenario. It has even been shown that survivors of torture have high rates of mental illness (Gamble et al., 2020). A systematic review corroborated the results of this research by concluding that female prisoners are at higher risk for physical and mental health problems (McGinley \& McMillan, 2019). The review also showed that the prevalence of head injury among female prisoners was higher than that of male prisoners. The risk of head injury in the general 
Research, Society and Development, v. 11, n. 1, e49611125288, 2022

(CC BY 4.0) | ISSN 2525-3409 | DOI: http://dx.doi.org/10.33448/rsd-v11i1.25288

population is twice as high in men as in women (McGinley \& McMillan, 2019), which shows that the situation in prisons is indeed different. Another literature review of productions on the prison system in Brazil pointed out that women reported more than men suffering from verbal and sexual aggression, falls, suicide attempts, homicide and stabbing with a knife (Ferreira et al., 2020). If this suffering of women in prison it's a serious problem (Carvalho et al., 2021) and is greater than that of men, as these recent surveys and others suggest (Moraes et al., 2020), it is worth asking whether the treatment given to them has been worse than the treatment given to men. They may be more victims of torture than men. If this is true, non-OPCAT ratifying countries, having a higher rate of adult women than the rest, would be more prone to crimes of torture. And because they have not joined the OPCAT, the systems of oversight of places of detention under international law to prevent torture do not apply to them.

Although our study did not involve statistical tests to compare the size of the adult prison population versus the young prison population, the results in the samples showed very different orders of magnitude. This was already expected, because in many countries individuals under the age of 18 cannot be arrested, as is the case in Brazil (Brazil, 1990). When they commit crimes or acts similar to crimes, many legislations encouraged the application of alternative sentences to deprivation of liberty because they are still in a stage of formation. The Convention on the Rights of the Child determines that the penalty of arrest, detention, or imprisonment shall be used only as a last resort to persons under the age of 18, and for the shortest period necessary (United Nations, 1989).

Still, on the profile of the prison population, attention was drawn to the fact that, in the last three years analyzed, the total rates of prisoners were statistically higher in countries that did not ratify the OPCAT. Perhaps this demonstrates a trend, which can only be confirmed in future prospective studies. Bearing this in mind, the same analysis carried out previously about women is valid. If the prison population is the most vulnerable to crimes of torture, the countries with the largest prison population become the countries most prone to these crimes. In the period 2017 to 2019 countries not committed to the OPCAT had a higher total incarceration rate than those committed. However, the OPCAT preventive systems do not apply to those countries that had the highest rates.

Regarding the percentage of prisoners without a sentence, the statistical tests applied to the data from our survey allow us to conclude that the situation of countries committed to the OPCAT is no different from that of non-committed countries. The first article of the CAT, when defining torture, clarifies that pain or suffering that solely results from legitimate sanctions will not be considered torture (United Nations, 1984). Being in prison without a sentence is a legitimate act from a legal point of view. But what about from the point of view of human dignity? Even in convictions arising from regular processes, with ample production of evidence, the possibility of convicting an innocent person is not ruled out. The chance is undoubtedly greater in cases where the custodian is held in detention without a final judgment. This situation can last for many months, so much so that one of the indicators in this study is people imprisoned without a sentence for more than 12 months. It cannot be said that the pains and sufferings of an innocent person imprisoned for months or even years awaiting a sentence are the consequences of legitimate sanctions. We could not even talk about sanctions in the face of an individual's innocence. There is no legal basis in international law to regard the situation of a prisoner without a sentence as inhuman or degrading treatment. This gap in the legal system seems to have had an impact on our findings, as being committed to the OPCAT did not imply any difference in the scenario in this regard. The prohibition of torture in the law is still very much associated with physical violence, situations of beatings. But emotional and psychological violence and inhumane treatment can take other forms.

As for prison capacity, there was also no difference in the percentage of prison capacity between the two groups of countries. Furthermore, all the results (without any exception) showed prison overcrowding in all the years analyzed, that is, with average percentages of overcrowding above 100\%. There is no doubt that overcrowding itself implies inadequate 
Research, Society and Development, v. 11, n. 1, e49611125288, 2022

(CC BY 4.0) | ISSN 2525-3409 | DOI: http://dx.doi.org/10.33448/rsd-v11i1.25288

treatment of weights (Santos et al., 2020; Sousa et al., 2020). Whether this inadequacy necessarily constitutes a situation of torture or cruel, inhuman and degrading treatment or punishment is something that can be analyzed on a case-by-case basis. But the fact is that an overcrowded place of restriction of liberty is not able to respect the human dignity of its prisoners. One of the aims of the OPCAT preventive mechanisms set out in Article 19 is to regularly review the treatment of prisoners to improve their conditions (United Nations, 2002). Our results showed that this OPCAT forecast did not affect the prison occupation indicator.

The findings regarding the death rates of prisoners were the most surprising. In most cases, countries committed to the OPCAT had the highest rates, and in some cases, particularly in suicide, these differences were statistically significant. It is not possible to assume that protective legislation such as the OPCAT could be associated with worsening indicators. The truth is that it is not uncommon that after the appearance of a new law, data gets worse at first (Cole, 2015; Hathaway, 2002). The literature explains this phenomenon in two ways. First, it may be that the law has increased the interpretation of a phenomenon so that what was previously not considered criminal now becomes (Hathaway, 2002). In the case of torture of prisoners, for example, the CAT itself forced the states parties to consider torture as a crime. Thus, more criminal cases will be counted, which does not necessarily mean that there has been a factual worsening. Another factor that may explain this apparent worsening after the adoption of the law is the fact that the matter started to receive attention from the authorities (Goodman \& Jinks, 2003). There will be greater inspection and greater effort to notify violations. In this case, notifications would also increase, but worsening would be related to a kind of over-reporting, without this indicating an increase in the number of cases.

\section{Final Considerations}

The protection of the human right to non-torture is indeed effective when measures are taken to prevent it. The OPCAT is the international legal instrument that establishes prevention mechanisms, but its adherence is substantially lower than that of the CAT, which works mostly with repressive measures. Countries that have not ratified the OPCAT are those with prison populations most vulnerable to torture, as they have achieved the highest incarceration rates for adult women and, in recent years, the highest prison population rates in total. There is a legal weakness about the protection of those in custody unsentenced and overcrowding in prisons. The law does not accept this fact as a possible situation of inhuman or degrading treatment, at least not explicitly. In addition, these were the only cases in which no statistically significant difference was observed between the scenarios of both groups of countries.

Our study, while focusing specifically on the OPCAT, can also serve as a basis for future studies aimed at measuring the effects of other international human rights treaties. The literature lacks research in this regard. Major international efforts are being made to establish pacts that guarantee human rights. Knowing whether the practice has been impacted by these laws is of fundamental importance for planning future actions. Therefore, it is necessary to monitor and measure the evolution of respect for human rights and we believe that our research contributes in this regard. There are basic human rights, which violation can no longer be tolerated anywhere in the world and under any circumstances. The right not to torture is one of them.

We suggest that further investigations be carried out to monitor the ability of other international treaties to change the population's life situation. For human rights to improve they need to be measured. Without these metrics, it is not possible to understand the real situation of their violations, nor to know if the context is progressively improving, stagnant, or worsening over time. Therefore, science can contribute to improving people's quality of life by producing data tools that are capable of changing policies and tracking countries' human rights performance. 
Research, Society and Development, v. 11, n. 1, e49611125288, 2022

(CC BY 4.0) | ISSN 2525-3409 | DOI: http://dx.doi.org/10.33448/rsd-v11i1.25288

\section{Acknowledgments}

This study was financially supported by National Council for Scientific and Technological Development (CNPq).

\section{References}

American States, 17955, Pact of San José (1969). https://treaties.un.org/doc/publication/unts/volume\%201144/volume-1144-i-17955-english.pdf

Beco, G. (2011). The Optional Protocol to the Convention against Torture and other Cruel, Inhuman or Degrading Treatment or Punishment (the OPCAT) in Europe: Duplication or Reinforcement? Maastricht Journal of European and Comparative Law, 18(3), 257-274. https://doi.org/10.1177/1023263X1101800303

Brazil, Lei 8.069, Estatuto da Criança e do Adolescente (1990). http://www.planalto.gov.br/ccivil_03/leis/18069.htm

Carvalho, E. R. de O., Mateus, K. S., Lima, K. da S., Silva, J. B., \& Uchida, R. R. (2021). Self-injury and suicide attempt in incarcerated women: Prevalence and risk factors. Research, Society and Development, 10(7), e9710715788. https://doi.org/10.33448/rsd-v10i7.15788

Cole, W. M. (2015). Mind the Gap: State Capacity and the Implementation of Human Rights Treaties. International Organization, 69(2), 405-441. https://doi.org/10.1017/S002081831400040X

Council of Europe, European Convention on Human Rights 34 (1950). https://www.echr.coe.int/documents/convention_eng.pdf

Edwards, A. (2008). THE OPTIONAL PROTOCOL TO THE CONVENTION AGAINST TORTURE AND THE DETENTION OF REFUGEES. International and Comparative Law Quarterly, 57(4), 789-825. https://doi.org/10.1017/S0020589308000596

Ferreira, A. P., Silva, P. M. C. A., Godinho, M. R., \& Nichele, C. da S. T. (2020). Análise do sistema prisional brasileiro: Revisão sistemática da situação de saúde na população privada de liberdade. Interfaces Científicas, 8(3), 365-385.

Fletcher, A. (2012). Australia and the OPCAT. Alternative Law Journal, 37(4), 233-237. https://doi.org/10.1177/1037969X1203700404

Gamble, A., Amin Ahmed, A. M., Hassan Rahim, S., \& Hartman, J. (2020). The effects of a combined psychotherapy and physiotherapy group treatment program for survivors of torture incarcerated in an adult prison in Kurdistan, Iraq: A pilot study. Torture Journal, 30(2), 58-76. https://doi.org/10.7146/torture.v30i2.119199

Goodman, R., \& Jinks, D. (2003). Measuring the Effects of Human Rights Treaties. Ejil, 14(1), 171-183.

Hardwick, N., \& Murray, R. (2019). Regularity of OPCAT visits by NPMs in Europe. Australian Journal of Human Rights, 25(1), 66-90. https://doi.org/10.1080/1323238X.2019.1588054

Hathaway, O. A. (2002). Do Human Rights Treaties Make a Difference? The Yale Law Journal, 111, 1935-2042. https://doi.org/10.2307/797642

Kim, T. K. (2015). T test as a parametric statistic. Korean Journal of Anesthesiology, 68(6), 540. https://doi.org/10.4097/kjae.2015.68.6.540

Limentani, G. B., Ringo, M. C., Ye, F., Bergquist, M. L., \& McSorley, E. O. (2005). Beyond the t-Test: Statistical equivalence testing. Analytical Chemistry, 77(11), 221A-226A. https://pubs.acs.org/doi/10.1021/ac053390m

McGinley, A., \& McMillan, T. (2019). The prevalence, characteristics, and impact of head injury in female prisoners: A systematic PRISMA review. Brain Injury, 33(13-14), 1581-1591. https://doi.org/10.1080/02699052.2019.1658223

Moraes, L. C. de, Souza, L. M. de, Fragoso, M. F., Oliveira, V. F. de, \& Carlesso, J. P. P. (2020). A ordem civilizadora da barbárie: O sistema prisional feminino no brasil. Research, Society and Development, 9(3), e197932769. https://doi.org/10.33448/rsd-v9i3.2769

Morettin, P. A., \& Bussab, W. de O. (2010). Estatistica basica. Saraiva.

Murray, R., Steinerte, E., Evans, M. D., \& Hallo de Wolf, A. (2011). The Optional Protocol to the UN Convention Against Torture. Oxford; Oxford University Press.

Nguyen, S. (2013). Treaty Design for Protecting Human Rights: Evidence from the Convention Against Torture and Its Optional Protocol. Annual Meeting of the American Political Science Association, 44.

Nichele, C. da S. T., \& Ferreira, A. P. (2020). Tratados internacionales de derechos humanos: Efectos sobre la salud de la mujer. Memorias del Instituto de Investigaciones en Ciencias de la Salud, 18(3), 55-66. https://doi.org/10.18004/mem.iics/1812-9528/2020.018.03.55

Nichele, C. da S. T., Horta, M. A. P., \& Ferreira, A. P. (2021a). Saúde da mulher: Papel dos pactos internacionais na evolução da proteção aos direitos humanos. Revista Brasileira em Promoção da Saúde, 34, 1-14. https://doi.org/10.5020/18061230.2021.10766

Nichele, C. da S. T., Horta, M. A. P., \& Ferreira, A. P. (2021b). Effects of the Optional Protocols to the Convention on the Rights of the Child on the causes of child death: A statistical study on a global scale. Cadernos Ibero-Americanos de Direito Sanitário, 10(4), 48-65. https://doi.org/10.17566/ciads.v10i4.819

Nielsen, R. A., \& Simmons, B. A. (2015). Rewards for Ratification: Payoffs for Participating in the International Human Rights Regime? International Studies Quarterly, 59(2), 197-208. https://doi.org/10.1111/isqu.12142 
Research, Society and Development, v. 11, n. 1, e49611125288, 2022

(CC BY 4.0) | ISSN 2525-3409 | DOI: http://dx.doi.org/10.33448/rsd-v11i1.25288

Nowak, M., Birk, M., \& Monina, G. (Eds.). (2019). The United Nations Convention against Torture and its Optional Protocol: A commentary (Second edition). Oxford University Press.

OHCHR. (2021). Convention against Torture and Other Cruel, Inhuman or Degrading Treatment or Punishment [Map]. Office of the United Nations High Commissioner for Human Rights United Nations. https://indicators.ohchr.org/

Palmer, A., Tomkinson, J., Phung, C., Ford, N., Joffres, M., Fernandes, K. A., Zeng, L., Lima, V., Montaner, J. S., Guyatt, G. H., \& Mills, E. J. (2009). Does ratification of human-rights treaties have effects on population health? The Lancet, 373(9679), 1987-1992. https://doi.org/10.1016/S0140-6736(09)60231-2

Santos, F. da S., Gouvêa, R. J. F., Bezerra Neto, F. das C., Caiana, C. R. A., \& Victor, G. P. (2020). As condições do sistema penitenciário brasileiro em contraste com os direitos fundamentais da mulher encarcerada. Research, Society and Development, 9(7), e732974602. https://doi.org/10.33448/rsd-v9i7.4602

Sousa, F. B. de, Soares, J. de F., Bezerra Neto, F. das C., Caiana, C. R. A., Medeiros, A. C. de, Silva, E. P., França Júnior, R. P., Félix, M. da C. S., Wanderley, H. G. F., \& Maracajá, P. B. (2020). Sistema prisional brasileiro: Infraestrutura, rebeliões e administração de crises. Research, Society and Development, 9(7), e633974342. https://doi.org/10.33448/rsd-v9i7.4342

Sveaass, N., \& Madrigal-Borloz, V. (2017). The preventive approach: OPCAT and the prevention of violence and abuse of persons with mental disabilities by monitoring places of detention. International Journal of Law and Psychiatry, 53, 15-26. https://doi.org/10.1016/j.ijlp.2017.06.001

Tait, C. A., Abdillahi, I., Wong, W., Smith-Cannoy, H., \& Siddiqi, A. (2019). Can the health effects of widely-held societal norms be evaluated? An analysis of the United Nations convention on the elimination of all forms of discrimination against women (UN-CEDAW). BMC Public Health, 19(1), 279. https://doi.org/10.1186/s12889-019-6607-6

Tyler, N., Miles, H. L., Karadag, B., \& Rogers, G. (2019). An updated picture of the mental health needs of male and female prisoners in the UK: Prevalence, comorbidity, and gender differences. Social Psychiatry and Psychiatric Epidemiology, 54(9), 1143-1152. https://doi.org/10.1007/s00127-019-01690-1

United Nations, General Assembly Resolution 217 A, Universal Declaration of Human Rights (1948).

United Nations, Assembly Resolution 39/46, Convention against Torture and Other Cruel, Inhuman or Degrading Treatment or Punishment (1984). https://www.ohchr.org/en/professionalinterest/pages/cat.aspx

United Nations, Assembly Resolution 44/25, Convention on the Rights of the Child (1989). https://www.ohchr.org/en/professionalinterest/pages/crc.aspx

United Nations, Resolution A/RES/57/199, Optional Protocol to the Convention against Torture and other Cruel, Inhuman or Degrading Treatment or Punishment (2002). https://www.ohchr.org/Documents/ProfessionalInterest/cat-one.pdf

UNODC. (2019). Data United Nations Office on Drugs and Crime (Prison). United Nations. https://dataunodc.un.org/

Weller, P. (2019). OPCAT monitoring and the Convention on the Rights of Persons with Disabilities. Australian Journal of Human Rights, 25(1), 130-149. https://doi.org/10.1080/1323238X.2019.1588056

White, M. (2019). The role and scope of OPCAT in protecting those deprived of liberty: A critical analysis of the New Zealand experience. Australian Journal of Human Rights, 25(1), 44-65. https://doi.org/10.1080/1323238X.2019.1588055

Wilson, A., \& Daar, A. S. (2013). A Survey of International Legal Instruments to Examine Their Effectiveness in Improving Global Health and in Realizing Health Rights. Journal of Law, Medicine \& Ethics, 41(1), 89-102. https://doi.org/10.1111/jlme.12007

Wolf, A. H., \& Watson, J. (2009). Navigating the Boundaries of Prevention: The Role of Opcat in Deportations with Diplomatic Assurances. Netherlands Quarterly of Human Rights, 27(4), 525-566. https://doi.org/10.1177/016934410902700404 